\title{
MENINGKATKAN PRESTASI BELAJAR SISWA PADA MATERI ENERGI LISTRIK MELALUI PENDEKATAN SAINTIFIK
}

\author{
Dede Dahyo $^{1)}$ \\ ${ }^{1}$ SMPN 2 Japara Kabupaten Kuningan
}

APA Citation: Dahyo, D. (2017). Meningkatkan Prestasi Belajar Siswa Pada Materi Energi Listrik Melalui Pendekatan Saintifik. Quagga: Jurnal Pendidikan dan Biologi, 9(2), 18-22. doi: 10.25134/quagga.v9i02.751.

\begin{abstract}
Abstrak: Penelitian tindakan kelas ini dilatar belakangi oleh rendahnya hasil ketuntasan siswa pada materi hubungan energi dan daya listrik hanya mencapai 58\% dari jumlah 33 siswa. Penelitian tindakan kelas ini dilaksanakan terhadap siswa kelas IX di SMP Negeri 2 Pasawahan Kabupaten Kuningan. Solusi tindakan yang digunakan adalah dengan menerapkan pendekatan saintifik sehingga memfokuskan siswa untuk mencari dan menggali sendiri informasi dan solusi dari masalah yang dihadapi dari materi energy listrik. . Penelitian ini dinyatakan berhasil bila kriteria ketuntasan mencapai lebih dari 80\%. Berdasarkan hasil penelitian tersebut diketahui pada siklus bahwa melalui pendekatan saintifik pada materi energy listrik nilai KKM siswa meningkat menjadi $76 \%$ dan pada siklus kedua KKM siswa meningkat kembali menjadi 91\%, maka dengan hasil tersebut maka dapat disimpulkan bahwa penerapan pendekatan saintifik dapat meningkatkan prestasi siswa pada materi energy listrik pada siswa kelas IX SMP Negeri 2 Pasawahan Kabupaten Kuningan.
\end{abstract}

Kata Kunci: prestasi belajar materi energi listrik, pendekatan saintifik.

\begin{abstract}
This classroom action research was motivated by the low results of students' completeness in the matter of energy and electrical power relations which only reached 58\% of the total 33 students. This classroom action research was conducted on class IX students at Pasawahan 2 Public Middle School, Kuningan Regency. The solution to the action used is to apply a scientific approach that focuses students to search for and explore information themselves and solutions to problems faced by electrical energy material. . This study was declared successful if the completeness criteria reached more than 80\%. Based on the results of the study, it was found in the cycle that through the scientific approach to the material of electrical energy the KKM value of students increased to $76 \%$ and in the second cycle the KKM students increased again to $91 \%$, so with these results it can be concluded that the application of scientific approaches material for electrical energy in class IX SMP Negeri 2 Pasawahan Kuningan District.
\end{abstract}

Keywords: learning achievement of electrical energy material, scientific approach.

\section{PENDAHULUAN}

Permendiknas No.20 Tahun 2007 menyatakan bahwa:" Ulangan harian adalah kegiatan yang dilakukan secara periodik untuk mengukur pencapaian kompetensi pesertadidik setelah menyelesaikan satu Kompetensi Dasar (KD) atau lebih ". Dengan dilaksanakan ulangan dan menganalisis hasil ulangan tersebut, seorang guru dapat melihat sejauh mana pencapaian ketuntasan belajar siswa baik secara individual maupun klasikal dalam proses pembelajaran. yaitu dengan cara membandingkan capaian hasil belajaran siswa dengan standar yang seharusnya dicapai.

Mengacu pada prinsip belajar tuntas (mastery learning) ketuntasan belajar dapat dilihat secara klasikal maupun secara individu. Secara klasikal ketuntasan belajara dinyatakan telah tuntas jika sekurang-kurangnya $85 \%$ dari siswa dalam kelas yang bersangkutan telah memenuhi Kriteria Ketuntasan Minimal (KKM) dan secara individual ketuntasan belajar dinyatakan telah tuntas jika siswa telah mencapai KKM yang telah ditetapkan oleh guru berdasar pada perhitungan penetapan KKM untuk setiap KD yang diampu pada semester berjalan.

Hasil analisis Ulangan Siswa SMP Negeri 2 Pasawahan Tahun pelajaran 2014/2015 di Kelas IX.1 pada KD.3.4 tentang Mendeskripsikan hubungan energi dan daya listrik serta pemanfaatannya dalam kehidupan sehari-hari, dengan KKM 70, ternyata bahwa ketuntasan secara klasikal baru mencapai 58\% dari jumlah siswa 33 orang, artinya masih ada 14 siswa yang secara individual belum mencapai KKM. Dengan demikian pembelajaran belum tuntas sehingga perlu diadakan remedial atau perbaikan.

Penelitian Tindakan Kelas ini dilakukan dengan tujuan untuk mengetahui bahwa penggunaan pendekatan saintifik dapat meningkatkan ketuntasan belajar siswa pada 
Quagga: Jurnal Pendidikan dan Biologi

Volume 9, Nomor 2, Juli 2017

materi energy listrik pada kelas IX.3 SMP Negeri 2 Pasawahan Kabupaten Kuningan.

\section{HASIL DAN PEMBAHASAN}

\section{Analisis Data Awal}

Ketuntasan Belajar siswa hasil ulangan formatif KD.3.4 tentang materi energy listrik sebagaimana disajikan dalam table 1 .

Tabel 1. Ketuntasan Belajar Hasil Ulangan Formatif

\begin{tabular}{ccccc}
\multicolumn{5}{c}{ Formatif } \\
No & Uraian & Nilai & $\begin{array}{c}\text { Jumlah } \\
\text { Siswa }\end{array}$ & $\begin{array}{c}\text { Prosentase } \\
\text { ketuntasan } \\
\text { Klasikal }\end{array}$ \\
\hline 1 & $\begin{array}{c}\text { Belum } \\
\text { Tuntas } \\
(\mathrm{BT})\end{array}$ & $\leq 70$ & 14 & 42 \\
2 & $\begin{array}{c}\text { Tuntas } \\
(\mathrm{T})\end{array}$ & $\geq 70$ & 19 & 58 \\
& & & &
\end{tabular}

Masih terdapat 14 orang siswa atau $42 \%$ siswa yang belum tuntas dalam pengertian bahwa siswa-siswa tersebut pada pembelajaran KD. 3.4 tentang materi energy listrik belum menguasai secara standar minimal sebagaimana yang disyaratkan yaitu mencapai nilai sama dengan atau lebih dari nilai 70 .

Terdapat 19 orang siswa atau $58 \%$ siswa yang telah tuntas dalam pengertian siswa-siswa tersebut telah menguasai pembelajaran KD 3.4 tentang energy listrik.

Berdasar materi learning bahwa ketuntasan belajar siswa secara klasikal minimal mencapai lebih besar atau sama dengan $85 \%$, oleh sebab itu terdapat sekitar $27 \%$ atau lebih yang perlu ditingkatkan.

\section{Analisis Data Tindakan}

\section{Analisis Data Tindakan Siklus 1}

Pelaksanaan tindakan siklus I ini dilakukan pada hari Selasa tanggal 4 Nopember 2014. Waktu pelaksanaan jam ke 2 dan ke 3 dimulai pukul 8.20 sampai dengan pukul 09.40 ( 80 menit). Pelaksanaan ini dilakukan oleh peneliti, dan rekan sejawat guru mata pelajaran IPA. satu orang. Rekan sejawat ini bertugas untuk mencatat berbagai aktivitas di kelas dan mengamati proses pembelajaran selama tindakan berlangsung dengan menggunakan intrumen yang sudah disiapkan

Proses pembelajaran dilaksanakan mengacu pada Rencana Pelaksanaan Pembelajaran (RPP) revisi yang telah disusun, yaitu terdiri atas kegiatan pendahuluan selama 5 menit, kegiatan inti selama 60 menit dan kegiatan penutup selama 15 menit.Kegiatan inti meliputi kegiatan
p-ISSN 1907-3089, e-ISSN 2651-5869

https://journal.uniku.ac.id/index.php/quagga

pengamatan dan mencatat hasil percobaan dilakukan selama 15 menit, memberikan kesempatan untuk bertanya dan mengarahkan selama 10 menit, mencari informasi dan mengolah data yang dipandu dengan Lembar Kegiatan Peserta Didik (LKPD) selama 25 menit, mempresentasikan dan pengumpulan hasil kerja selama 10 menit.

Pada kegiatan penutup dilakukan kegiatan mencatat rangkuman materi pembelajaran dan pelaksanaan tes hasil belajar.

Hasil observasi pelaksanaan proses pembelajaran dengan penerapan pendekatan saintifik pada siklus I disajikan pada Tabel 2 di bawah ini:

Tabel 2. Data Hasil Observasi Proses Pembelajaran

\begin{tabular}{|c|c|c|c|}
\hline No & Komponen & Target & Prosentase \\
\hline 1 & $\begin{array}{l}\text { Kegiatan } \\
\text { Pendahuluan }\end{array}$ & $\begin{array}{l}\text { Melakukan } \\
\text { apersepsi, } \\
\text { motivasi, } \\
\text { penyampaikan } \\
\text { tujuan } \\
\text { pembelajaran. }\end{array}$ & $81,25 \%$ \\
\hline \multirow{4}{*}{2} & \multirow{4}{*}{ Kegiatan Inti } & $\begin{array}{l}\text { Menguasai } \\
\text { materi dan } \\
\text { menerapkan } \\
\text { metode } \\
\text { pembelajaran }\end{array}$ & $87,50 \%$ \\
\hline & & $\begin{array}{l}\text { Menerapkan } \\
\text { pendekatan } \\
\text { pembelajaran } \\
\text { saintifik }\end{array}$ & $87,50 \%$ \\
\hline & & $\begin{array}{l}\text { Pemanfaatan } \\
\text { sumber belajar/ } \\
\text { media dan } \\
\text { bahasa dalam } \\
\text { pembelajaran }\end{array}$ & $81,25 \%$ \\
\hline & & $\begin{array}{l}\text { Pelibatan siswa } \\
\text { dalam } \\
\text { pembelajaran }\end{array}$ & $81,25 \%$ \\
\hline \multicolumn{3}{|c|}{ Prosentase pemenuhan kegiatan inti } & $84,38 \%$ \\
\hline 3 & $\begin{array}{l}\text { Kegiatan } \\
\text { Penutup }\end{array}$ & $\begin{array}{l}\text { Menerapkan } \\
\text { langkah } \\
\text { menutup } \\
\text { pembelajaran }\end{array}$ & $81,25 \%$ \\
\hline \multicolumn{3}{|c|}{$\begin{array}{l}\text { Prosentase pemenuhan kegiatan } \\
\text { pembelajaran dalam RPP }\end{array}$} & $82,29 \%$ \\
\hline
\end{tabular}

Table 2. menunjukkan bahwa dari hasil pengamatan pemenuhan kegiatan pembelajaran materi Energy Listrik dengan menggunakan pendekatan saintifik sesuai dengan Rencana Pelaksanaan Pembelajaran (RPP) adalah sebesar $82,29 \%$. Pemenuhan kegiatan inti dalam proses pembelajaran sebesar $84,38 \%$, dimana prosentase terbesar dari pemenuhan target menguasai materi dan menerapkan metode pembelajaran sebesar $87,50 \%$ dan pemenuhan target menerapkan 
Quagga: Jurnal Pendidikan dan Biologi

Volume 9, Nomor 2, Juli 2017

pendekatan pembelajaran saintifik sebesar $87,50 \%$. Dalam hal ini menunjukan bahwa proses pembelajaran pada kegiatan inti telah menggunakan pendekatan saintifik.

Analisis Data Tindakan Siklus 2

Pelaksanaan tindakan siklus I ini dilakukan pada hari Selasa tanggal 11 Nopember 2014. Waktu pelaksanaan jam ke 2 dan ke 3 dimulai pukul 8.20 sampai dengan pukul 09.40 ( 80 menit). Pelaksanaan ini dilakukan oleh peneliti, dan rekan sejawat guru mata pelajaran IPA. satu orang. Rekan sejawat ini bertugas untuk mencatat berbagai aktivitas di kelas dan mengamati proses pembelajaran selama tindakan berlangsung dengan menggunakan intrumen yang sudah disiapkan.

Proses pembelajaran dilaksanakan mengacu pada Rencana Pelaksanaan Pembelajaran (RPP) revisi yang telah disusun, yaitu terdiri atas kegiatan pendahuluan selama 5 menit, kegiatan inti selama 60 menit dan kegiatan penutup selama 15 menit.

Kegiatan inti meliputi kegiatan pengamatan dan mencatat hasil percobaan dilakukan selama 15 menit, memberikan kesempatan untuk bertanya dan mengarahkan selama 10 menit, mencari informasi dan mengolah data yang dipandu dengan Lembar Kegiatan Peserta Didik (LKPD) selama 25 menit, mempresentasikan dan pengumpulan hasil kerja selama 10 menit.

Pada kegiatan penutup dilakukan kegiatan mencatat rangkuman materi pembelajaran dan pelaksanaan tes hasil belajar.

Hasil observasi pelaksanaan proses pembelajaran dengan penerapan pendekatan saintifik pada siklus I disajikan pada Tabel 3. di bawah ini:

Tabel 3. Data Hasil Observasi Proses Pembelajaran

\begin{tabular}{|c|c|c|c|}
\hline No & Komponen & Target & Prosentase \\
\hline 1 & $\begin{array}{l}\text { Kegiatan } \\
\text { Pendahuluan }\end{array}$ & $\begin{array}{l}\text { Melakukan } \\
\text { apersepsi, } \\
\text { motivasi, } \\
\text { penyampaikan } \\
\text { tujuan } \\
\text { pembelajaran. }\end{array}$ & $87,50 \%$ \\
\hline \multirow{3}{*}{2} & \multirow{3}{*}{ Kegiatan Inti } & $\begin{array}{l}\text { Menguasai materi } \\
\text { dan menerapkan } \\
\text { metode } \\
\text { pembelajaran }\end{array}$ & $93,75 \%$ \\
\hline & & $\begin{array}{l}\text { Menerapkan } \\
\text { pendekatan } \\
\text { pembelajaran } \\
\text { saintifik }\end{array}$ & $93,75 \%$ \\
\hline & & $\begin{array}{l}\text { Pemanfaatan } \\
\text { sumber belajar/ } \\
\text { media dan bahasa } \\
\text { dalam } \\
\text { pembelajaran }\end{array}$ & $93,75 \%$ \\
\hline
\end{tabular}

p-ISSN 1907-3089, e-ISSN 2651-5869

https://journal.uniku.ac.id/index.php/quagga

\begin{tabular}{|c|c|c|c|}
\hline & & $\begin{array}{l}\text { Pelibatan siswa } \\
\text { dalam } \\
\text { pembelajaran }\end{array}$ & $87,50 \%$ \\
\hline \multicolumn{3}{|c|}{ Prosentase pemenuhan kegiatan inti } & $92,19 \%$ \\
\hline 3 & $\begin{array}{l}\text { Kegiatan } \\
\text { Penutup }\end{array}$ & $\begin{array}{l}\text { Menerapkan } \\
\text { langkah menutup } \\
\text { pembelajaran }\end{array}$ & $87,50 \%$ \\
\hline \multicolumn{3}{|c|}{$\begin{array}{c}\text { Prosentase pemenuhan kegiatan pembelajaran } \\
\text { dalam RPP }\end{array}$} & $89,06 \%$ \\
\hline
\end{tabular}

Table 3. menunjukkan bahwa dari hasil pengamatan pemenuhan kegiatan pembelajaran materi Energy Listrik dengan menggunakan pendekatan saintifik sesuai dengan Rencana Pelaksanaan Pembelajaran (RPP) adalah sebesar $89,06 \%$.

Pemenuhan kegiatan inti dalam proses pembelajaran sebesar $92,19 \%$, dimana prosentase terkecil dari pemenuhan target pelibatan siswa dalam pembelajaran dan kegiatan penutup yaitu sebesar $87,50 \%$ dan pemenuhan target menerapkan pendekatan pembelajaran saintifik sebesar 93,75\%. Dalam hal ini menunjukan bahwa proses pembelajaran pada kegiatan inti telah menggunakan pendekatan saintifik.

Keberhasilan pelaksanaan pembelajaran ditentukan dari kinerja guru dan perubahan tingkah laku siswa berupa aktivitas siswa yang diharapkan. Gambaran perkembangan kinerja guru dapat dilihat pada table 4. di bawah ini:

Tabel 4. Hasil Pemenuhan Proses Pembelajaran

\begin{tabular}{|c|c|c|}
\hline No & Kinerja Guru & $\begin{array}{c}\text { Pemenuhan } \\
\text { Kinerja }\end{array}$ \\
\hline 1 & Siklus I & $82,29 \%$ \\
\hline 2 & Siklus II & $93,75 \%$ \\
\hline
\end{tabular}

Tabel 4. menunjukkan bahwa kinerja guru dalam melaksanakan pembelajaran secara umum menunjukkan peningkatan.

Hal ini dapat dilihat dari rata-rata tingkat pencapaian setiap aspek pada penilaian kinerja guru. Rata-rata tingkat pencapaian tertinggi dari penilaian kinerja guru terdapat di siklus II pada aspek pemenuhan kegiatan inti sebesar 92, 19\% Adapun rata-rata tingkat pencapain terendah dari penilaian kinerja guru terdapat di siklus I pada aspek pemanfaatan sumber belajar/ media dan bahasa dalam pembelajaran, yaitu: $81,25 \%$. Secara keseluruhan dari komponen kegiatan pembelajaran menunjukkan bahwa hampir seluruhnya indikator penilaian telah dimunculkan oleh guru pada setiap aspek penilaian di setiap siklus yang dilaksanakan.

Peningkatan pelaksanaan pembelajaran yang tercemin dari peningkatan kinerja guru dalam 
Quagga: Jurnal Pendidikan dan Biologi

Volume 9, Nomor 2, Juli 2017

menerapkan pendekatan saintifik di setiap siklus, ternyata memberikan perubahan perolehan hasil belajar siswa materi energy listrik. Hal ini terlihat dari hasil belajar siswa yang mengalami peningkatan, seperti terdapat pada tabel 5. di bawah ini.

Tabel 5. Prestasi siswa Hasil Tes Tulis

\begin{tabular}{|c|c|c|c|}
\hline No & NAMA & $\begin{array}{c}\text { Prestasi } \\
\text { Belajar } \\
\text { Siklus I }\end{array}$ & $\begin{array}{c}\text { Prestasi } \\
\text { Belajar } \\
\text { Siklus II }\end{array}$ \\
\hline 1 & ADANG SUDRAJAT & 70 & 80 \\
\hline 2 & AFIF HAFIFUDHIN & 70 & 90 \\
\hline 3 & $\begin{array}{l}\text { AFIFAH } \\
\text { FATIHATULIA }\end{array}$ & 70 & 70 \\
\hline 4 & AJENG MARTASARI & 90 & 100 \\
\hline 5 & DAPID ABDURROHIM & 80 & 80 \\
\hline 6 & DARA MUTIA & 60 & 80 \\
\hline 7 & DEVA RAMADANI & 80 & 90 \\
\hline 8 & ENDRI AGUSTIAN & 50 & 80 \\
\hline 9 & $\begin{array}{l}\text { FAHALA FRISA } \\
\text { GUSTIAR }\end{array}$ & 80 & 80 \\
\hline 10 & FAJAR DEWANTO & 70 & 90 \\
\hline 11 & HADINA WAWESI & 90 & 90 \\
\hline 12 & HANNY FEBYANTI P & 80 & 80 \\
\hline 13 & HENI FEBRIANI & 70 & 80 \\
\hline 14 & IDA WULANDARI & 70 & 90 \\
\hline 15 & JAJANG NURJAMAN & 60 & 80 \\
\hline 16 & LINDASARI & 80 & 80 \\
\hline 17 & $\begin{array}{l}\text { LUSIYANA } \\
\text { MAIYSURI }\end{array}$ & 70 & 80 \\
\hline 18 & MELIA PUSPITA SARI & 80 & 80 \\
\hline 19 & MUHAMAD RIZKY & 70 & 80 \\
\hline 20 & NANDA DILA APONDI & 90 & 90 \\
\hline 21 & NOVAN SETIAWAN & 50 & 50 \\
\hline 22 & PANJI KURNIA & 70 & 80 \\
\hline 23 & REGAR & 50 & 60 \\
\hline 24 & $\begin{array}{l}\text { RIO FAHRI } \\
\text { ALAMSYAH }\end{array}$ & 50 & 70 \\
\hline 25 & RISMA AGUSTINA & 90 & 90 \\
\hline 26 & RIYAN SETIAWAN & 70 & 80 \\
\hline 27 & ROHIMAN & 60 & 60 \\
\hline 28 & $\begin{array}{l}\text { SILVIA AYU } \\
\text { MARYAM }\end{array}$ & 90 & 100 \\
\hline 29 & SUPRIADI & 60 & 70 \\
\hline 30 & TESY PRATIWI & 80 & 100 \\
\hline 31 & VANI OKTAVIANI & 70 & 80 \\
\hline 32 & $\begin{array}{l}\text { YOHANA } \\
\text { ANGGRAENI }\end{array}$ & 80 & 100 \\
\hline 33 & YULIANI WAHYUNI & 80 & 90 \\
\hline & JUMLAH & 2.380 & 2.700 \\
\hline & Rata-rata & 72,12 & 81,82 \\
\hline
\end{tabular}

Pembahasan peningkatan Ketuntasan belajar siswa disajikan Tabel 6 . berikut ini:

Tabel 6. Hasil Pemenuhan Proses Pembelajaran

\begin{tabular}{|c|l|c|c|c|}
\hline No & \multicolumn{1}{|c|}{ Komponen } & $\begin{array}{c}\text { Data } \\
\text { Awal }\end{array}$ & Siklus I & $\begin{array}{c}\text { Siklus } \\
\text { II }\end{array}$ \\
\hline 1 & $\begin{array}{l}\text { Ketuntasan } \\
\text { Belajar Klasikal }\end{array}$ & $58 \%$ & $76 \%$ & $91 \%$ \\
\hline 2 & $\begin{array}{l}\text { Jumlah siswa } \\
\text { yang Tuntas }\end{array}$ & $\begin{array}{c}19 \\
\text { orang }\end{array}$ & $\begin{array}{c}25 \\
\text { orang }\end{array}$ & $\begin{array}{c}30 \\
\text { orang }\end{array}$ \\
\hline
\end{tabular}

p-ISSN 1907-3089, e-ISSN 2651-5869

https://journal.uniku.ac.id/index.php/quagga

Tabel 6. menyajikan peningkatan persentase pencapaian ketuntasan belajar klasikal dan jumlah siswa yang tuntas belajar mulai dari data awal hingga siklus II. Dari persentase 58\% $91 \%$, diperoleh ketuntasan belajar siswa tertinggi terdapat pada siklus II, yaitu: $91 \%$. Ketuntasan belajar terendah dari hasil belajar siswa terdapat pada data awal, yaitu: $58 \%$. Secara keseluruhan, ketuntasan belajar siswa menunjukkan peningkatan mulai dari data awal hingga siklus II. Secara keseluruhan, jumlah siswa yang tuntas belajar terus meningkat dari data awal hingga siklus II. Dengan demikian dapat disampaikan bahwa penerapan pendekatan saintifik ternyata mampu meningkatkan prestasi belajar siswa dan ketuntasan belajar siswa secara klasikal.

\section{SIMPULAN DAN SARAN}

Berdasarkan rumusan permasalahan, tujuan dan hasil penelitian tentang penggunaan pendekatan saintifik pada materi energy listrik di kelas IX.3 SMP Negeri 2 Pasawahan Kabupaten Kuningan, maka penelitian dapat menyimpulkan sebagai berikut:

1. Terdapat peningkatan prestasi belajar siswa materi energy listrik melalui penerapan pendekatan saintifik bagi siswa kelas IX.3 di SMP Negeri 2 Pasawahan Kabupaten Kuningan. Hal ini dapat dilihat dari perolehan hasil tes tertulis semakin meningkat jumlah siswa yang memperoleh prestasi lebih dari Kriteria Ketuntasan Minimal mulai dari 19 orang , 25 orang hingga mencapai 30 orang pada siklus II.

2. Pelaksanaan pembelajaran dengan menggunakan pendekatan saintifik pada materi energy listrik di kelas IX.3 SMP Negeri 2 Pasawahan dapat meningkatkan ketuntasan belajar secara klasikal. Hal ini dapat dilihat dari perolehan persentase ketuntasan belajar klasikal hasil tes tertulis semakin meningkat hingga mencapai nilai persentase $91 \%$ pada

siklus II. Hasil ini menunjukkan bahwa target belajar tuntas (mastery learning) yang ditetapkan sekurang-kurangnya $85 \%$ dari siswa dalam kelas yang bersangkutan telah memenuhi Kriteria Ketuntasan Minimal (KKM) telah tercapai.

Berdasarkan hasil kesimpulan di atas, maka saran yang dapat disampaikan sesuai hasil penelitian ini, ialah sebagai berikut:

1. Bagi Siswa 
Quagga: Jurnal Pendidikan dan Biologi

Volume 9, Nomor 2, Juli 2017

a. Dalam mengerjakan Lembar Kegiatan Peserta Didik (LKPD), siswa hendaknya lebih teliti dalam membaca dan mengerjakan secara sistematis.

b. Dalam menentukan satuan besaran, siswa hendaknya memahami prosesnya, sehingga dapat menentukan satuan dengan benar.

2. Bagi Guru

a. Guru diharapkan dapat menerapkan pendekatan saintifik pada proses pembelajaran.

b. Dalam merancang dan melakukan penilaian pembelajaran untuk mengatasi kesulitan belajar siswa, guru hendaknya menyesuaikan dengan indicator dan tujuan pembelajaran.

3. Bagi Lembaga

Dapat menjadikan motivasi bagi guru dalam upaya-upaya perbaikan pembelajaran ke arah pembelajaran aktif, inovatif, kreatif, efektif dan menyenangkan.

\section{REFERENSI}

Depdiknas, (2004), Penelitian Tindakan Kelas (PTK), Materi Pelatihan Terintegrasi Sains PTBK, Jakarta, Depdiknas (2004), Model Pembelajaran Sains, Materi Pelatihan Sains PTBK, Jakarta, Depdiknas , (2004), Landasan Teori dalam Pengembangan Model Pembelajaran Sains, Materi Pelatihan Sains PTBK, Jakarta, Depdiknas , (2004), Media Pembelajaran Sains, Materi Pelatihan Sains PTBK, Jakarta, Depdiknas (2004), Penulisan Karya Ilmiah, Materi Pelatihan Sains PTBK, Jakarta, Depdiknas , (2004), Penilaian Berbasis Kelas dalam Pembelajaran Sains, Materi Pelatihan Sains PTBK, Jakarta, Depdiknas

Muhibbin Syah (2002), Psikologi Pendidikan dengan Pendekatan Baru, PT Remaja Rosdakarya, Bandung

Suryabrata (1987), Psikologi Pendidikan, Rajawali, Jakarta

Syaodih Sukmadinata (2003), Landasan Psikologi Proses Pendidikan, PT Remaja Rosdakarya, Bandung

Rizky Amelia (2013), Pendekatan saintifik, Pelatihan Pendamping Pendekatan
p-ISSN 1907-3089, e-ISSN 2651-5869

https://journal.uniku.ac.id/index.php/quagga

Saintifik, Pusat Pengembangan Tendik Kemendikbud, Jakarta

Winkel, W.S (1986), Psikologi Pendidikan dan Evaluasi Belajar, PT Gramedia, Jakarta

Yadi Rochyadi (2000), Kontruktivisme, Makalah disampaikan pada LKGI Biologi SMP ( tidak diterbitkan), Bandung 14-17 September 2000

Djalal, MF (1986). Penilaian Dalam Pengajaran Bahasa Asing. Malang: P3T IKIP Malang

Hamalik Oemar. (2001). Proses Belajar Mengajar. Bandung: Bumi Aksara.

Saifudin Azwar. (1996). Pengantar Psikologi Intelegensi. Jogyakarta: Pustaka Pelajar.

Majid, (2014). Strategi Pembelajaran. Bandung: PT. Remaja Rosdakarya. 